\title{
Effect of Spiral Elastic Band on Gait Function in Patients with Chronic Stroke
}

\author{
Ki hyun Baek', Hyoung won Lim²
}

'Department of Physical Therapy, Graduate school, Dankook University; ${ }^{2}$ Department of Physical Therapy, Dankook University, Cheonan, Korea

Purpose: This study examined the effects of a spiral elastic band for the walking function on patients with chronic stroke.

Methods: Twenty one chronic stroke patients were recruited and divided randomly into the experimental group and control group. Both groups performed mat exercises and gait training three times a week for four weeks, and gait training was applied to the experimental group with additional spinal elastic bands.

Results: The results of this research were as follows. The 10MWT measurements showed that the velocities within and between the groups decreased significantly, and the results of TUG showed significant decreases in velocities after the interventions in both the control group and experimental group. On the other hand, there were no significant differences between the control and experimental group. The FRT measurements showed significantly increased stride lengths within and between the groups. The measurements of the stride length, stride velocity, cadence, and step length showed significant improvement within the groups, but there was no significant difference between the groups. The measurement of stance showed that the non-paralytic patients had a significant increase in the rates within the groups and a significant difference was observed between the groups.

Conclusion: Spiral elastic bands are an effective intervention method for rehabilitation programs to enhance the walking function in the clinical field. A treatment needs to be developed for patients with walking problems due to various disorders by investigating the action mechanism of spiral elastic bands.

Keywords: Stroke, Elastic band, Balance, Walking function

\section{서 론}

뇌졸중은 많은 노인들에게 장애의 주요 요인으로 중요한 사회적 난 제이다. 의학 및 기술의 발전, 의료의 질 향상 그리고 건강의 기여도 증가는 뇌졸중 발병률 감소에 기여해 왔다. 그러나 이러한 뇌졸중 발 병률의 감소에도 불구하고 인구의 노령화의 증가와 더불어 발병 후 생존율이 개선됨에 따라 뇌졸중 생존자의 수가 증가하고 있다.!

뇌졸중 환자는 마비로 인한 신체 전반의 근육 약화와 고유수용성 감각(proprioception)의 인식 문제, 감각의 변화, 비정상적인 운동 제어 등이 발생한다. 이로 인해 뇌졸중 환자는 몸통과 어깨, 골반 등의 부정 렬뿐 만 아니라 척추의 정렬을 변화시켜 비대칭적 자세를 야기한다. 또 한 비정상적인 신체 균형, 불충분한 체중 이동과 섬세한 운동기능의 상실 등이 나타나며 이에 따라 기립과 보행에 장애를 받게 된다.23 이러 한 기립과 보행능력의 장애로 인하여 뇌졸중 환자는 독립적인 이동이
힘들기 때문에 독립적인 보행능력의 회복은 재활에서 중요한 목표가 된다. ${ }^{4}$ 선행연구에 따르면 급성 뇌졸중 환자에서 소수의 경우에만 보 행 능력이 회복된다고 하였으며, 보행에 대한 예후는 환자의 후속적인 독립성 수준을 결정하기 때문에 뇌졸중 환자와 가족에게 중요하다고 보고하였다. 따라서 뇌졸중 환자에게서 기능적 보행을 향상시키는 것 은 환자의 일상생활 활동과 삶의 질 향상에 매우 중요하다.

뇌졸중 환자는 임상적으로 마비 측의 근육 약화, 근육 긴장도의 변화, 비정상적인 움직임 패턴 등의 문제가 동반되며, 손상된 운동 제 어로 인하여 기능적 보행이 저하된다. ${ }^{6}$ 특별히 뇌졸중 환자의 하지 근 력은 기능적 보행을 예측하는데 중요한 요소이다. 기능적 보행에서 하지 근력의 약화는 보행의 안정성과 속도에 문제를 일으키며, 특히 엉덩관절 폄근은 보행의 빠르기와 무릎의 자세 조절, 보행 중 자세의 안정성에 많이 관여한다. ${ }^{8}$ 뇌졸중 환자의 대부분은 신체 한쪽 부위의 마비 즉, 편마비가 많이 발생하는데 보행 시 마비측 하지에 충분한 체 
중부하를 못하며, 비마비 측에 대부분의 체중부하를 하여 걷는 비정 상적인 보행이 나타난다. ${ }^{9}$ 이러한 마비 측의 근력 약화는 원활한 근육 활성화와 마비 측으로의 체중이동을 방해하여 보행 중 발생하는 정 상적인 체중이동을 방해한다. 따라서 약화된 마비측 하지 근력을 향 상시키고, 비마비 측으로 이동한 무게중심을 마비 측으로 이동시키 는 재활훈련을 한다면 보행 중 신체의 안정성과 균형 조절이 향상될 것이다. ${ }^{9}$

뇌졸중 환자에서 신체가 적절하게 정렬되면, 반복적인 근육 재교 육을 통해 근육의 정확한 움직임을 인식하고, 손상된 뇌를 자극할 수 있는 적극적인 운동요법을 수행할 수 있다. ${ }^{10}$ 뇌졸중 환자의 기능적 활동 중에 잘못된 운동 패턴을 반복적으로 사용하면 뇌의 운동 영역 에서 이러한 비정상적인 움직임을 인지하는 경향이 있어 결과적으로 정상적인 운동 프로그램을 만들지 못하게 된다."

발 처짐(drop foot)으로 인한 발목의 불안정성은 마비 측의 체중이 동을 감소시킨다고 하였다. ${ }^{12}$ 뇌졸중 환자의 신체 정렬에 대한 중재로 치료용 슈트 ${ }^{13}$ 와 조절식 하네스, ${ }^{14}$ 첨족 변형을 감소시키고자 적용되 는 단하지 보조기(ankle foot orthosis, $\mathrm{AFO}$ )는 신체 정렬을 교정하기 위한 주요 중재로 사용되고 있다. ${ }^{15}$ 이전 연구에서 $\mathrm{AFO}$ 적용은 보행 성능과 균형을 향상시킨다고 보고하였다. 반면 슈트는 착용이 매우 복잡하고 하네스(harness)나 $\mathrm{AFO}$ 는 정적 보조기로 관절의 움직임이 제한적이고 딱딱한 재질로 인해 압력에 매우 민감하다.

측만증의 경우 등허리엉치뼈보조기(thoracolumbosacral orthosis, $\mathrm{TLSO}$ 로 정적 보강을 하는데 가장 일반적으로 사용된다. 이것은 변 형의 진행을 제어하기 위하여 외부 압력이나 힘을 가함으로써 척추 를 안정화 시킨다. ${ }^{16}$ 보조기는 안정화 되는데 도움은 주지만 가동성 이 떨어져 움직임에 제한을 주고 있다. 이러한 개념을 토대로 동적 보 조기인 dynamic spinecor (SC)가 개발되었으며 이것은 골반의 기본 버 팀대를 두고 탄성밴드를 이용하여 척추의 곡선 유형과 교정 동작에 따라 밴드의 적절한 장력과 회전을 통하여 동적 교정을 할 수 있도록 고안되었다. 사선형 밴드를 연결하여 척추의 안정성을 높이고 균형적 인 무게중심을 할수 있도록 유도한다. 능동 피드백을 통한 교정 운동 은 신경근 통합을 목표로 한다. 이러한 방법은 어느 정도의 통제된 이 동성을 허용하고 잠재된 척추 교정 운동의 신경근 조절을 재교육하 고 유지할 수 있는 기회를 제공한다..$^{17}$

측만증에서는 정적 보조기의 단점으로 착용 후 일상생활을 하기 힘들고 장시간 착용에 어려움을 보완하기 위해서 동적 보조기에 대 한 연구가 많이 진행되고 있다. 보조기를 착용하고 운동이나 치료, 더 나아가 일상생활이 치료적으로 도움이 되도록 연구되고 있다. 골반 의 3 차원적 움직임에 대하여 대각선의 보조 장치는 무게중심을 움직 이는데 있어 도움이 된다고 하였다. 무게중심이동과 보행에 속도는 뇌졸중 치료에 있어 중요한 요소로 작용된다. ${ }^{18}$ 측만증 환자에게 치
료목적의 훈련을 위해 대각선 탄성밴드를 적용한 연구는 보고되었으 나, ${ }^{19}$ 뇌졸중 환자에게 적용된 바가 없었다.

나선형 탄성밴드는 뇌졸중과 같은 한쪽 마비 측을 위해 고안된 것 으로 발목부터 어깨까지 착용이 가능하다. 나선형 탄성밴드는 회전 을 통한 밴드의 탄성으로 근육의 안정성을 확보해주고 원위부에서 근위부 방향으로 당겨주는 방식으로 정방향 패턴과 역방향 패턴이 있는데 환자에 따라 약한 부분을 보호하거나 강화시키는 방향으로 쓸 수 있다. 발 처짐을 방지하고 골반부터 하지 전체에 내회전을 촉진 하여 선자세의 안정성을 확보할 수 있도록 만든 밴드이다. 나선형 탄 성 밴드는 착용이 간단하며 나선형으로 밴드가 연결되어 척추의 안 정성을 높일 수 있고 무게중심의 균형을 유지할 수 있도록 도와준 다. ${ }^{17}$ 따라서 선 자세에서 대칭성을 확보할 수 있는 유용한 재활 운동 프로그램이 될 수 있을 것이다.

그러므로 본 연구에서는 나선형 탄성밴드를 성인 뇌졸중 환자에 게 적용하여 보행기능에 미치는 영향을 조사하고자 한다.

\section{연구 방법}

\section{1. 연구대상}

본 연구의 대상은 2018 년 7월 20일부터 8 월 26일까지 충남 천안 $\mathrm{D}$ 병원 에서 뇌졸중으로 진단을 받은 환자 중 발병이 6개월 이상 된 만성 환 자 그리고 20 분 이상 보행훈련이 가능하며 의사소통이 가능한 21 명 을 대상으로 실시하였으며 제비 뽑기를 통하여 무작위로 진행되었다 (table 1). 본 연구의 대상자 선정 기준은 다음과 같다.

가. 뇌졸중으로 진단을 받은 편마비 환자.

나. 발병이 6개월 이상 된 만성 환자.

다. 한국판 간이정신상태검사(K-MMSE) 25점 이상인 자.

라. 최근 1 년 이내 정형외과 수술을 받지 않은 자.

마. 20 분 이상 보행 훈련이 가능한자.

Table 1. General characteristics of each group

\begin{tabular}{lccc}
\hline \multirow{2}{*}{ Variables } & \multicolumn{2}{c}{ Group } & \\
\cline { 2 - 3 } & $\begin{array}{c}\text { Control } \\
(\mathrm{n}=10)\end{array}$ & $\begin{array}{c}\text { Experimental } \\
(\mathrm{n}=11)\end{array}$ & $\mathrm{p}$ \\
\hline Male (\%)/Female (\%) & $8(80.0) / 2(20.0)$ & $7(63.6) / 4(36.4)$ & 0.730 \\
Age (year) & $51.56 \pm 5.03$ & $51.58 \pm 11.84$ & 0.698 \\
Height (cm) & $166.50 \pm 8.38$ & $165.46 \pm 9.09$ & 0.646 \\
Weight (kg) & $65.98 \pm 9.25$ & $69.56 \pm 7.08$ & 0.358 \\
K- MMSE (point) & $28.90 \pm 1.60$ & $28.09 \pm 1.92$ & 0.260 \\
Duration of illness (month) & $13.10 \pm 4.79$ & $15.91 \pm 4.11$ & 0.119 \\
Paralyzed side Lt(\%)/Rt (\%) & $6(60.0) / 4(40.0)$ & $5(45.5) / 6(54.5)$ & 0.819 \\
\hline
\end{tabular}

Mean \pm SD 
본 연구에 앞서 대상자들에게 연구의 목적과 실험 전반에 대한 내 용을 충분히 설명하고 자발적 동의서를 받고 진행하였다.

\section{2. 실험방법}

\section{1) 연구절차 및 중재방법}

본 연구에서는 피험자를 각각 실험군 11 명과 대조군 10 명으로 무작 위 할당하였다. 두 그룹 모두 주 3 회 4 주간 중재프로그램으로 매트운 동과 보행훈련을 실시하였으며 실험군에게는 보행 훈련 시 추가적으 로 나선형 탄성 밴드를 적용하여 보행 훈련을 실시하였다. 나선형 탄 성밴드(SH10045, Kun Rehab center, Korea)는 총 길이 4,600×50 mm로 길이는 조절하여 사용하였다. 착용 방법은 마비측 어깨에 걸어서 체 간에 한 바퀴 감고 마비측 다리로 감아 대퇴골 앞쪽 절반을 지나 한 바퀴 감고 슬개골 아래 경골 조면 아래를 한 바퀴 돌아 경골 절반을 지나 발바닥으로 밴드가 지나 위로 올려 부착하였다. 탄성에 강도는 환자에 따라 조금씩 다르지만 너무 강하게 하여 피가 안 통하거나 너 무 약하게 하여 흘러내리지 않도록 주의하였다(figure 1).

평가는 Legsys+ 검사, 10 meter walking test (10MWT), timed up and go test (TUG), functional reach test (FRT)를 실시하였다. 각 검사는 D병 원 운동치료실에서 중재 전과 후에 실시하였다. 모든 검사는 검사의 신뢰도를 높이기 위해 임상 5 년차 이상의 숙련된 동일한 물리치료사 에 의해 진행하였다.

\section{2) 평가도구}

(1) 기능적 보행 검사(LEGSys+system)

기능적 보행을 검사하기 위해 보행에 대한 3 차원 운동 변수들을 측

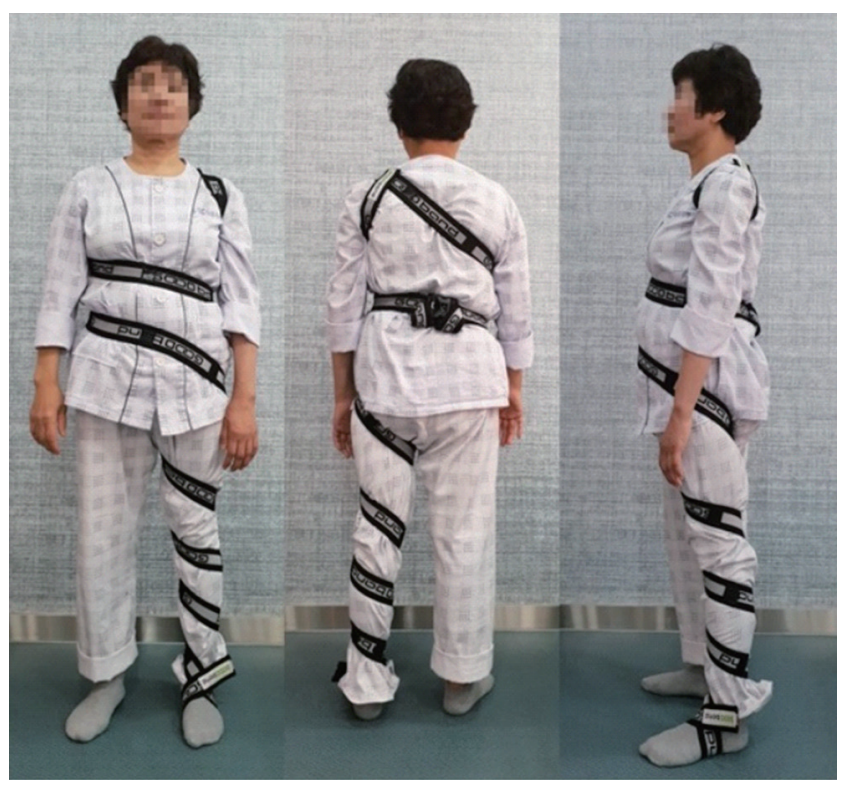

Figure 1. Wearing way of Spiral Elastic Band
정할 수 있는 LEGSys+ System (BioSensics, Cambridge, Massachusetts, USA)을 사용하였다. LEGSys+는 5 개의 무선 착용식 센서 $(5.0 \mathrm{~cm} \times 4.2$ $\mathrm{cm} \times 1.2 \mathrm{~cm}$ )를 부착하여 블루투스로 컴퓨터에 연결하며 각 센서에 는 세 개의 축으로 자이로스콥, 가속도계 및 자력계가 포함된다. 실험 장소에 구애 받지 않고 실험이 가능하며 한 걸음 길이, 걸음 속도, 한 발짝 거리 및 분속 수, 보행균형과 같은 시공간적 데이터(spatiotemporal data)를 기록하였다.

(2) $10 \mathrm{M}$ 보행검사(10 meter walking test, 10MWT)

$10 \mathrm{M}$ 보행 검사시 총 $14 \mathrm{~m}$ 의 직선거리를 측정해두고 처음 $2 \mathrm{~m}$ 와 마지 막 $2 \mathrm{~m}$ 는 치료사가 알게 표시해두었다. 보행 속도측정은 초시계로 측 정하고 환자를 연습하게 하여 적응하도록 한 후 3 회 측정한 후 평균 값을 사용하였다. 검사자는 안전을 위하여 가까운 곳에 낙상을 대비 하였고 검사하는 동안 적절한 휴식을 가지며 실시하였다.

(3) 일어서서 걷기 검사(timed up and go test, TUG) 평편한 바닥에 팔걸이가 있는 의자를 놓고 앉아서 실험자의 출발 신 호와 함께 $3 \mathrm{~m}$ 를 왕복하고 돌아와 다시 앉는 시간을 3 회 반복 실시하 여 평균시간을 측정하였다. 이때 타인의 도움을 받지 않고 평상시 착 용하던 신발과 보조도구는 사용할 수 있다. 시간은 핸드폰 초시계를 이용하여 측정하였다.

(4) 기능적 팔 뻗기 검사(functional reach test, FRT)

FRT는 대상자 발바닥이 어깨 너비만큼 벌리고 발이 표시된 발판에 서서 팔을 앞으로 올리고 주먹을 가볍게 쥐고 타겟바(target bar)에 주 먹을 댄다. 치료사가 신호하면 타겟바를 밀라고 지시한다. 피험자의 우세팔의 어깨뼈봉우리 높이에 기준점에 줄자를 사용하여 종료지 점 세 번째 손가락 손허리뼈의 머리를 기준점으로 사용한다. 2-3회 연 습 후 3 회 실시하여 평균 결과 값을 데이터로 사용하였다.

\section{3. 분석방법}

본 연구에서는 실험군과 대조군의 대상자의 수가 적어 정규분포를 가정할 수 없기 때문에 비모수 검정을 실시하였다. 연구대상자들의 일반적 특성에 관한 실험군과 대조군 간의 동질성 검사는 MannWhiteney test와 Chi-square test를 통하여 실시하였다.

실험군과 대조군의 각 집단 내 중재 전과 후의 $10 \mathrm{MWT}, \mathrm{FRT}, \mathrm{TUG}$, 보행 변인의 변화는 Wilcoxon signed ranks test를 실시하였고, 두 집단 간 중재 전과 후의 변화량의 차이를 보기 위하여 Mann-Whiteney test 를 실시하였다. 본 연구에서 수집된 데이터는 SPSS ver 21. 프로그램으 로 사용하였으며, 통계학적 유의성을 검정하기 위한 유의수준 $a$ 는 0.05 로 하였다. 
결 과

\section{1. 중재 전, 후 그룹 내, 그룹 간 10MWT와 TUG 비교}

각 그룹 내, 그룹 간 중재 전과 후의 $10 \mathrm{MWT}, \mathrm{TUG}$ 의 변화에 대한 분 석 결과는 다음과 같다(Table 2). 10MWT에서 실험군의 경우 보행속 도가 유의하게 감소하였으나 $(\mathrm{p}<0.05)$, 대조군의 경우 유의한 변화가 없었다 $(\mathrm{p}>0.05)$. 또한 중재 전과 후의 $10 \mathrm{MWT}$ 의 변화량은 대조군과
비교하여 실험군에서 속도가 더 많이 감소하였고 통계적으로 유의하 였다(p<0.05). TUG에서는 실험군과 대조군 모두에서 유의하게 감소 하였다 $(\mathrm{p}<0.05)$. 반면 중재 전과 후의 $\mathrm{TUG}$ 변화량은 그룹 간 유의한 차이를 보이지 않았다 $(\mathrm{p}>0.05)$.

\section{2. 중재 전, 후 그룹 내, 그룹 간 FRT 비교}

각 그룹 내, 그룹 간 중재 전과 후의 FRT의 변화에 대한 분석 결과는

Table 2. The comparison of 10MWT and TUG between pre and post-intervention in each group and between the groups

\begin{tabular}{|c|c|c|c|c|c|}
\hline Variables & Group & Pre & Post & Difference of pre and post & $p$ \\
\hline \multirow[t]{3}{*}{ 10MWT (sec) } & Control & $14.27 \pm 7.29$ & $13.78 \pm 6.47$ & $0.49 \pm 1.17$ & 0.285 \\
\hline & Experimental & $15.14 \pm 12.55$ & $12.10 \pm 8.82$ & $3.04 \pm 4.25$ & $0.004^{*}$ \\
\hline & $\mathrm{p}$ & & & $0.041^{*}$ & \\
\hline \multirow[t]{3}{*}{ TUG (sec) } & Control & $17.44 \pm 8.45$ & $15.56 \pm 6.64$ & $1.88 \pm 2.09$ & $0.022^{*}$ \\
\hline & Experimental & $16.39 \pm 11.00$ & $13.54 \pm 8.33$ & $2.85 \pm 3.01$ & $0.003^{*}$ \\
\hline & $\mathrm{p}$ & & & 0.439 & \\
\hline
\end{tabular}

Mean \pm SD, 10MWT: 10 meter walking test, TUG: timed up and go test, $p<0.05$.

Table 3. The comparison of FRT between pre and post-intervention in each group and between the groups

\begin{tabular}{llccc}
\hline Variables & \multicolumn{1}{c}{ Group } & Pre & Post & Difference of pre and post \\
\hline FRT $(\mathrm{cm})$ & Control & $32.80 \pm 6.02$ & $34.35 \pm 6.11$ & $-1.55 \pm 3.10$ \\
& Experimental & $30.83 \pm 4.39$ & $36.32 \pm 3.46$ & $-5.49 \pm 2.94$ \\
& $p$ & & & $0.008^{*}$ \\
\hline
\end{tabular}

Mean $\pm S D, F R T$ : functional reach test, $p<0.05$.

Table 4. The comparison of spatio-temporal parameters during gait between pre and post-intervention in each group and between the groups

\begin{tabular}{|c|c|c|c|c|c|}
\hline Variables & Group & Pre & Post & Difference of pre and post & $p$ \\
\hline \multirow[t]{3}{*}{ Stride velocity (sec) } & Control & $0.66 \pm 0.29$ & $0.79 \pm 0.32$ & $0.13 \pm 0.11$ & $0.008^{*}$ \\
\hline & Experimental & $0.68 \pm 0.28$ & $0.86 \pm 0.35$ & $0.18 \pm 0.15$ & $0.011^{*}$ \\
\hline & $\mathrm{p}$ & & & 0.314 & \\
\hline \multirow[t]{3}{*}{ Stride length $(\mathrm{cm})$} & Control & $87.80 \pm 28.72$ & $98.30 \pm 30.27$ & $10.50 \pm 5.76$ & $0.005^{*}$ \\
\hline & Experimental & $79.27 \pm 37.17$ & $101.82 \pm 33.79$ & $22.55 \pm 34.27$ & $0.013^{*}$ \\
\hline & $\mathrm{p}$ & & & 0.197 & \\
\hline \multirow[t]{3}{*}{ Cadence $(\mathrm{cm})$} & Control & $87.60 \pm 15.51$ & $93.00 \pm 14.71$ & $5.40 \pm 8.03$ & $0.047^{*}$ \\
\hline & Experimental & $90.47 \pm 13.15$ & $98.43 \pm 12.17$ & $7.96 \pm 8.30$ & $0.016^{*}$ \\
\hline & $\mathrm{p}$ & & & 0.387 & \\
\hline \multirow[t]{3}{*}{ Step length_paralyzed side (cm) } & Control & $43.49 \pm 14.97$ & $49.39 \pm 14.44$ & $5.90 \pm 3.74$ & $0.007^{*}$ \\
\hline & Experimental & $42.64 \pm 16.98$ & $50.91 \pm 18.90$ & $8.27 \pm 6.13$ & $0.007^{*}$ \\
\hline & $\mathrm{p}$ & & & 0.349 & \\
\hline \multirow[t]{3}{*}{ Step length_non paralyzed side (cm) } & Control & $44.29 \pm 15.56$ & $49.30 \pm 17.04$ & $5.01 \pm 4.18$ & $0.017^{*}$ \\
\hline & Experimental & $46.00 \pm 14.35$ & $51.45 \pm 15.34$ & $5.45 \pm 8.37$ & $0.036^{*}$ \\
\hline & $\mathrm{p}$ & & & 0.918 & \\
\hline \multirow[t]{3}{*}{ Stance_paralyzed side (\%) } & Control & $59.51 \pm 4.31$ & $57.89 \pm 3.35$ & $1.63 \pm 3.46$ & 0.139 \\
\hline & Experimental & $58.85 \pm 5.70$ & $59.19 \pm 5.26$ & $-0.34 \pm 3.06$ & 0.790 \\
\hline & $\mathrm{p}$ & & & 0.223 & \\
\hline \multirow[t]{3}{*}{ Stance_non paralyzed side (\%) } & Control & $67.51 \pm 7.64$ & $67.20 \pm 6.71$ & $0.31 \pm 2.00$ & 0.508 \\
\hline & Experimental & $67.20 \pm 7.31$ & $64.54 \pm 5.23$ & $2.66 \pm 2.50$ & $0.008^{*}$ \\
\hline & $\mathrm{p}$ & & & $0.036^{*}$ & \\
\hline
\end{tabular}

Mean $\pm S D, p<0.05$. 
다음과 같다(Table 3). FRT에서 실험군의 경우 유의하게 증가되었다 $(\mathrm{p}<0.01)$. 대조군의 경우 유의한 변화가 없었다 $(\mathrm{p}>0.05)$. 또한 중재 전 과 후의 변화량은 실험군에서 더 많이 증가되었고 통계적으로 유의 하였다 $(\mathrm{p}<0.01)$.

\section{3. 중재 전, 후 그룹 내, 그룹 간 보행의 시공간적 변인 비교}

중재 전, 후 그룹 내, 그룹 간 보행의 시공간적 변인 비교 결과 걸음 속 도에서는 실험군과 대조군 모두에서 유의하게 속도가 증가되었다 $(\mathrm{p}<0.05)$ 한 걸음 길이에서도 실험군과 대조군 모두에서 유의하게 증 가되었다 $(\mathrm{p}<0.05)$. 분속수에서는 실험군과 대조군 모두에서 유의하 게 증가하였다. $(\mathrm{p}<0.05)$. 마비 측과 비마비 측의 한 발짝 거리에서는 실험군과 대조군 모두에서 증가하였으며, 통계적으로 유의하였다 $(\mathrm{p}<0.05)$. 비마비 측에서의 디딤기 비율은 실험군 그룹 내에서 증가하 였으며, 그룹 간 비교에서는 변화량이 더 컸으며 통계적으로 유의하 였다 $(\mathrm{p}<0.05)$. 비마비 측 디딤기 비율의 대조군 그룹 내에서는 중재 전과 후 유의한 변화는 보이지 않았다 $(\mathrm{p}>0.05)$. 또한 마비측 디딤기 비율에서는 실험군과 대조군 모두에서 중재 전과 후 유의한 차이를 보이지 않았다 $(\mathrm{p}>0.05)$. 그룹 간의 걸음 속도, 한 걸음 길이, 분속 수, 한 발짝 거리 그리고 마비 측의 디딤기 비율의 결과 통계적으로 유의 한 차이가 없었다 $(\mathrm{p}>0.05)$ (Table 4).

\section{고 찰}

본 연구는 만성 뇌졸중 환자에게 나선형 탄성밴드 적용이 보행 속도, 균형 능력, 시공간적인 변인에 미치는 영향을 알아보기 위해 시행하 였다. 뇌졸중 환자의 운동 회복과 기능적 보행 능력의 개선은 보행 속 도와 보행 변수에 따라 개선되며, ${ }^{20}$ 보행 속도의 향상은 가정에서 기 능과 삶의 질을 향상시킨다. ${ }^{21}$ 뇌졸중 환자에게 $\mathrm{AFO}$ 적용을 한 연구 에서 몸의 동요를 크게 줄이고 보행 속도의 개선을 보고하였다. 그러 나, 다른 보행 변인인 분속 수(cadence)와 한 걸음 길이(stride length)을 향상시키지는 못한다고 하였다. ${ }^{15}$ 다른 연구에서는 실내 보행속도에 서 탄력성 재질을 사용한 발목-발 보조기(ankle-foot orthosis, AFO)가 보행 속도에 영향을 주지 못한다고 하였다.22 이처럼 뇌졸중 환자에서 단하지 보조기의 적용은 상이한 결과를 보여주고 있다. 본 연구결과 에서 나선형 탄성밴드 적용 후 $10 \mathrm{MWT}$ 에서 집단 간 유의한 차이를 보였다. 가능한 설명으로는 나선형 탄성밴드 적용은 발발목 뿐만 아 니라 무릎과 골반 체간까지 지지하여 $\mathrm{AFO}$ 의 기능뿐만 아니라 신체 동요를 줄여 신체 안정화에 영향을 주어 보행속도의 증가를 가져온 것으로 사료된다.

뇌졸중 환자는 높은 낙상위험에 노출되어 있으며, TUG에 걸리는 시간은 낙상과 유의미하게 연관되어 있다. ${ }^{23}$ 뇌졸중 환자에게 코어 안
정화와 하지 근력운동을 적용하여 동적 균형을 본 결과 TUG 시간의 감소를 보고하였다. ${ }^{24}$ 또한 체간의 조절은 하지, 척추 분절, 골반과 흥 추 간의 적절한 협응이 이루어져야 하며, 이러한 협응의 결여는 뇌졸 중 환자의 균형과 보행 기능 장애에 중요한 요인이라고 하였다.25 이 연구에서 만성 뇌졸중 환자를 대상으로 침대와 스위스 볼(swiss ball) 을 기반으로 한 체간운동 요법(trunk control regimes)이 체간 조절, 균 형, 가동성, 신체기능, 그리고 지역사회로의 복귀를 조사한 연구에서 종속변인의 향상을 보고하였다. 본 연구결과 TUG검사는 집단 내에 서는 유의한 차이를 보였으나 집단 간에서는 유의한 차이를 보이지 않았다. 탄력적인 밴드를 이용한 물리적 압박력은 척추의 안정성을 증진시킬 수 있다고 하였다. ${ }^{26}$ 또한 상하지 근육의 기능적 움직임을 활성화하기 위해서는 척추의 안정성이 선행되어야 한다고 하였다. ${ }^{27}$ 본 연구에서 적용한 나선형 탄성밴드는 체간을 감싸 척추의 압박력 을 높이고, 마비 측의 보행 시 안정성을 증진시켜 보행을 개선하고자 하였다. 그러나, 본 연구에서는 반복적인 걷기만을 하였을 뿐 돌아서 기, 앉았다 일어서기 등의 훈련은 실시하지 않았다. 또한 TUG는 단순 보행이 아닌 어려운 과제를 동반해서 수행하기 때문에 나선형 탄성 밴드 착용 후 걷기 훈련만으로 영향을 주기는 어려웠을 것으로 생각 된다.

맨발 보행과 $\mathrm{AFO}$ 를 착용한 상태의 보행 비교 시 $\mathrm{AFO}$ 는 속도, 한 걸음 길이(step length) 및 균형을 크게 향상시키는 것으로 보고하였으 나, 발목 관절의 가쪽들림(pronated foot)을 막는데 효과적이지 못하다 고 하였다..$^{28}$ 또한 발의 가쪽들림 교정목적으로 heel-open $\mathrm{AFO}$ 를 개 발하여 보행 시 충분한체중 부하를 위해 뒤꿈치가 닿는 단계에서 뒤 꿈치 뼈 표면을 노출시키기 위해 절단하였다.' 이것은 뒤꿈치 뼈에 충 분한 쿠션을 허용하고 감각 피드백을 제공하여 가쪽들림의 힘을 감 소시킨다고 하였다. Motorized ankle stretcher (MAS)를 이용한 다른 연구에서는 발목 스트레칭 운동을 통해 뇌졸중 환자의 발목 관절 운 동, 균형 조절 및 보행능력을 연구한 결과 발목 주위의 고유수용성 감 각을 자극하여 균형조절능력과 발목 관절의 가동범위를 향상시켰다 고 보고하였다. ${ }^{30}$ 본 연구결과 FRT 검사에서 그룹 간 그룹 내 모두 유 의하게 증가한 결과를 나타냈다. 본 연구의 나선형 밴드는 선행연구 에서 사용한 중재 방법과 유사하게 뒤꿈치를 개방시켜서 감각입력을 증진시킬 수 있었으며, 발목관절을 지지하여 적극적인 외회전을 방지 하여 발목의 안정성을 증진시켜 균형 개선을 유도하고 밴드의 탄성 을 통하여 발목의 제한 없이 중립위치에 있을 수 있도록 한 것이라고 생각된다.

뇌졸중 환자의 보행특성으로는 느리고, 에너지를 많이 사용하며, 협응되지 못한 사지의 움직임을 특징으로 한다. ${ }^{31}$ 또한 비대칭적인 체 중 부하로 인하여 균형 능력은 감소한다고 하였다.32 편마비 환자를 대상으로 수중 트레드밀 훈련 전, 후 시공간적 보행 변인을 비교한 결 
과 보행 속도, 분속 수의 유의한 증가를 보고하였다. ${ }^{33}$ 그러나, 다른 연 구에서는 뇌졸중 환자 71 명을 대상으로 한 걸음 길이의 대칭성 변화 를 분석한 결과 속도, 균형 및 기능적 움직임의 향상에도 불구하고 보 행의 시공간적 변수의 대칭성을 개선하지는 못한다고 하였다. ${ }^{34}$ 다른 연구에서는 근전도 바이오피드백 중재 후 보행 속도와 보행 주기가 증가하였고, 보행 패턴의 대칭성을 향상시켰다고 보고하였다. ${ }^{35}$ 본 연 구에서도 실험군의 경우 이전 연구와 유사한 결과인 중재 후 비마비 측 디딤기 비율이 통계적으로 유의하게 감소를 보였으며 이것은 중재 후 보행의 시공간적 변수의 대칭성이 향상되었음을 의미한다. 뇌졸 중 환자의 트레드밀 훈련 동안 시각적 정보를 제공하여 보행의 대칭 을 향상시키고자 한 연구에서는 비마비 측의 한 발짝 거리는 증가되 었고 한 발짝 거리의 대칭 지수 개선을 보고하였다. ${ }^{36}$ 이들의 연구에 서는 비마비 측의 디딤기 시간이 유의하게 감소한 것을 볼 수 있었고 보행의 대칭이 향상된 것을 보여주었다. 비마비 측의 디딤기 기간에 서 유의한 차이가 났다는 것은 뇌졸중 환자들의 대칭적인 보행을 하 는데 있어 좋은 의미가 될 것이다. 본 연구의 다른 보행 변인인 걸음 속도, 한 걸음 길이, 분속 수에 대한 결과로는 중재 전후 집단 내에서 통계적으로 유의하게 증가하였으며, 실험군에서 더 많은 증가를 보였 으나 통계적으로 유의하지 않았다.

이전 연구에서 치료 중재 방법으로 $\mathrm{AFO}$, 체간운동요법, 트레드밀 등을 사용하여 만성 뇌졸중 환자의 보행기능의 많은 연구가 되어 왔 다. 본 연구에서 사용한 나선형 탄성밴드는 다른 연구에서 착용한 보 조기와 유사하지만 이전 연구들의 핵심요소들을 복합적으로 결합 하여 짧은 기간에도 불구하고 효과적인 연구가 된 것으로 생각된다.

편마비 환자의 보행을 보고한 다른 연구와 마찬가지로 본 연구에 서도 나선형 탄성밴드 적용이 환자의 균형 및 보행 능력을 향상시키 는데 효과적인 것으로 나타났다. 그러나, 몇 가지 제한점을 갖는다. 첫 째, 4 주라는 짧은 기간과 적은 표본크기로 일반화에 한계를 갖는다. 둘째, 나선형 탄성밴드 적용 시 압박력을 정량화하지 못하여 피험자 에게 동일한 압박력을 제공하지 못하였다. 셋째, 연구 결과에 영향을 줄 수 있는 중재 기간동안 피험자의 일상생활동작을 철저하게 통제 하지 못하였다. 향후 연구에서는 대상자 수와 중재기간을 늘리고 나 선형 탄성밴드에 대한 탄성의 압박력의 정량화 및 착용 시간의 효과 에 대한 연구가 필요할 것으로 사료된다.

\section{REFERENCES}

1. Kim P, Warren S, Madill H et al. Quality of life of stroke survivors. Qual Life Res.1999:8(4);293-301.

2. Ji JG. The effects of walking, massage and taping treatments on the serum inflammatory, serum lipids, electromyography, gait and life quality of stroke patients. Exerc Sci.2016:25(3);150-8.
3. Won SH, Kin JC, Oh DW. Effects of a novel walking training program with postural correction and visual feedback on walking function in patients with post-stroke hemiparesis. J Phys Ther Sci. 2015:27(8);2581-3.

4. Mauritz KH. Gait training in hemiplegia. Eur J Neurol.2002:9(1);23-9.

5. Wandel A, Jørgensen HS, Nakayama $\mathrm{H}$ et al, Prediction of walking function in stroke patients with initial lower extremity paralysis: the Copenhagen stroke study. Arch Phys Med Rehabil. 2000:81(6);736-8.

6. Sharp SA, Brouwer BJ. Isokinetic strength training of the hemiparetic knee: effects on function and spasticity. Arch Phys Med Rehabil. 1997: 78(11);1231-6.

7. Bohannon RW, Walsh S. Nature, reliability, and predictive value of muscle performance measures in patients with hemiparesis following stroke. Arch Phys Med Rehabil.1992:73(8):721-5.

8. Kin SG. Effect of treadmill gradient training on lower limb muscle activity in chronic Stroke patient. Journal of the Korea Academia-Industrial cooperation Society. 2012:13(1);220-6.

9. Yoon JS. The effect of ankle brace on the activity and balance of ankle muscles in stroke patients. Exercise Science. 2013;22(1):1-9.

10. Lee BH. Clinical usefulness of Adeli suit therapy for improving gait function in children with spastic cerebral palsy: a case study. J. Phys Ther Sci.2016:28(6);1949-52.

11. Page P, Frank C, Lardner R. Assessment and treatment of muscle imbalance: the Janda approach. Champaign, human kinetics. 2010.

12. Lee DJ. A study on effect of task-related training in water and on land for chronic stroke patient for a balance, functional performance and the quality of the life. Sahmyook University. Dissertation of Doctorate Degree. 2008.

13. Bailes AF, Greve K, Burch CK et al. The effect of suit wear during an intensive therapy program in children with cerebral palsy. Pediatr Phys Ther. 2011:23(2);136-42.

14. Katsuhira J, Miura N, Yasui T et al. Efficacy of a newly designed trunk orthosis with joints providing resistive force in adults with post-stroke hemiparesis. Prosthet Orthot Int, 2016:40(1);129-36.

15. Mojica JA, Nakamura R, Kobayashi T et al. Effect of ankle-foot orthosis (AFO) on body sway and walking capacity of hemiparetic stroke patients. Tohoku J Exp Med. 1988:156(4);395-401.

16. Labelle H, Dansereau J, Bellefleur C et al. Three-dimensional effect of the Boston brace on the thoracic spine and rib cage. Spine.1996:21(1); 59-64.

17. Gutman G, Benoit M, Joncas Jet al. The effectiveness of the SpineCor brace for the conservative treatment of adolescent idiopathic scoliosis comparison with the boston brace. Spine J. 2016:16(5);626-31.

18. Bear HR, Wolf SL. Modified emory functional ambulation profile: An outcome measure for the rehabilitation of poststroke gait dysfunction. Stroke.2001:32(4);973-9.

19. Coillard C, Circo AB, Rivard CH. SpineCor treatment for juvenile idiopathic scoliosis: SOSORT award 2010 winner. Scoliosis.2010:5(1);25.

20. Dettman MA, Linder MT, Sepic SB. Relationships among walking performance, postural stability, and functional assessments of the hemiplegic patient. Am J Phys Med. 1987:66(2);77-90.

21. Schmid A, Duncan PW, Studenski S et al. Improvements in speed-based gait classifications are meaningful. Stroke.2007:38(7);2096-100.

22. Cho SH, Song BB. The effects of elastic ankle-foot orthosis on balance and gait for the patients with stroke.JSER,2016;55(1):269-85. 
23. Kojima G, Masud T, Kendrick Det al. Does the timed up and go test predict future falls among british community-dwelling older people? prospective cohort study nested within a randomised controlled trial. BMC Geriatr.2015:15(1);32-8.

24. Kim DH, Yang JH, Kim YG et al. The effect of strengthening exercise of core muscles and lower limb extensor muscles on postural control and walking of stroke patients. Neurotherapy. 2012;16(1):9-16.

25. Karthikbabu S, Chakrapani M, Ganesan S et al. Efficacy of trunk regimes on balance, mobility, physical function, and community reintegration in chronic stroke: a parallel-group randomized trial. J Stroke Cerebrovasc Dis.2018:27(4);1003-11.

26. Wong MS, Cheng CY, Ng BK et al. The effect of rigid versus flexible spinal orthosis on the gait pattern of patients with adolescent idiopathic scoliosis. Gait Posture.2008:27(2);189-95.

27. Kisner C, Colby LA. Therapeutic exercise: foundations and techniques. 4th ed. Philadelphia, FA Davis Co.2002.

28. Cakar E, Durmus O, Tekin L et al. The ankle-foot orthosis improves balance and reduces fall risk of chronic spastic hemiparetic patients. Eur J Phys Rehabil Med. 2010:46(3);363-8.

29. Kim HJ, Chun MH, Kim HM et al. Effects on foot external rotation of the modified ankle-foot orthosis on post-stroke hemiparetic gait. Ann
Rehabil Med. 2013:37(4);516-22.

30. Yoo D, Son Y, Kim DH et al. Technology-assisted ankle rehabilitation improves balance and gait performance in stroke survivors: A randomized controlled study with 1-month follow-up. IEEE Trans Neural Syst Rehabil Eng. 2018:26(12);2315-23.

31. Kuan TS, Tsou JY, Su FC. Hemiplegic gait of stroke patients: the effect of using a cane. Arch Phys Med Rehabil. 1999:80(7);777-84.

32. Sackley CM, Baguly BI. Visual feedback after stroke with balance performance monitor: two single case studies. Clin Rehabil. 1993:7(3);189-95.

33. Park SW, Song CH. The effect of under-water treadmill training on gait ability in chronic stroke. JSER.2011;50(2):149-65.

34. Patterson KK, Mansfield A, Biasin L et al. Longitudinal changes in poststroke spatiotemporal gait asymmetry over inpatient rehabilitation. Neurorehabil Neural Repair. 2015:29(2);153-62.

35. Jonsdottir J, Cattaneo D, Recalcati M et al. Task-oriented biofeedback to improve gait in individuals with chronic stroke: motor learning approach. Neurorehabil Neural Repair. 2010:24(5);478-85.

36. Drużbicki M, Guzik A, Przysada G et al. Changes in gait symmetry after training on a treadmill with biofeedback in chronic stroke patients: a 6-month follow-up from a randomized controlled trial. Med Sci Monit. 2016:11(22);4859-68. 